\title{
Handmade Cloning for Embryo Production in Goat, Assam, India
}

\author{
Monika Borah ${ }^{1}$, Nikhil C. Nath², Probodh Borah ${ }^{1}$, Biju Borah ${ }^{3 *}$, \\ Girin Hazarika ${ }^{1}$ and Padma L. Borah ${ }^{4}$ \\ ${ }^{1}$ Department of Animal Biotechnology, College of Veterinary Science, Assam Agricultural \\ University, Khanapara, Guwahati, Assam, India \\ ${ }^{2}$ Department of Veterinary Physiology, College of Veterinary Science, Assam Agricultural \\ University, Khanapara, Guwahati, Assam, India \\ ${ }^{3}$ ICAR-NRC on Yak, Dirang, Arunachal Pradesh, India \\ ${ }^{4}$ Molbio Diagnostics Pvt. Ltd, Assam, India \\ *Corresponding author
}

\section{A B S T R A C T}

\begin{tabular}{|l|}
\hline Ke y w o r d s \\
Cloning, Embryo, Goat, \\
Handmade, Production
\end{tabular}

\section{Introduction}

In reproductive biotechnology, the "handmade cloning" (HMC) technique emerged as a new alternative technique for very expensive traditional somatic cell nuclear transfer technique.

HMC is a micromanipulator-free cloning technique for production of cloned embryo. The benefits of HMC are low equipment cost, a simple and rapid procedure, a person can be
In this study, oocytes were recovered from 200 numbers of goats' ovaries from different slaughterhouses for subsequent use in-vitro maturation, enucleation, reconstruction and embryo culture to produce cloned embryos. The collected oocytes were classified into three categories (Grade A, B and C) based on their appearance of homogenous granular ooplasm and layers of cumulus cells surrounding oocytes under a stereozoom microscope. The average oocyte recovery, In-vitro maturation and the enucleation rates were found to be 3.36 per ovary, 60.37 per cent and 75.52 per cent respectively. Two enucleated (demi) oocytes were fused to one fibroblast cells to produce reconstructed oocyte and the average success rate was recorded as 23.95 per cent. When the reconstructed oocytes were parthenogenetically activated, followed by in-vitro culture of embryos in mSOF media, the average clone embryo production was 6.38 per cent. Grade A oocytes yielded higher maturation rate and subsequent embryo production in-vitro. 
development of fibroblast cell monolayer from goat fetus and to develop cloned embryos by Fusion of goat somatic cell with oocyte.

\section{Materials and Methods}

The experiment was conducted in the State Biotech Hub (SBT), Department of Animal Biotechnology and the Department of Veterinary Physiology, College of Veterinary Science, Assam Agricultural University, Khanapara, Guwahati. Goat ovaries of adult animals were collected immediately after slaughter from local abattoirs of Guwahati, Assam. Ovaries were carried to the laboratory in a thermos flask containing warm $\left(32-35^{\circ} \mathrm{C}\right)$ sterile NSS fortified with antibiotic (Penicillin $\mathrm{G}-0.06 \mathrm{gm} / 1000 \mathrm{ml}$ ) and processed within 3 hours. The collected oocytes were then washed 5-6 times in washing medium and classified into three categories (Grade A, B and $C$ ) based on their appearance of homogenous granular ooplasm and layers of cumulus cells surrounding oocytes under a stereozoom microscope.

Grade A, B and C included oocytes surrounded by five or more complete layers of cumulus cells adhered to the zona pellucid, Oocytes surrounded by three or more complete layers of cumulus cells adhered to the zona pellucid and Oocytes surrounded by two complete layers of cumulus cells adhered to the zona pellucid respectively. The recovered oocytes were subjected to in-vitro maturation (IVM) in maturation medium for 24 hours under $\mathrm{CO}_{2}$ incubator at $38.5^{\circ} \mathrm{C}, 5 \%$ $\mathrm{CO}_{2}$ and $90-95 \%$ relative humidity (RH). The maturation evaluation was done by observing cumulus cell expansion and aceto-orcein staining for the presence of polar body. After IVM, oocytes were denuded by using hyaluronidase $(0.5 \mathrm{mg} / \mathrm{ml})$ to remove the cumulus cells surrounding the oocytes and 400 denuded oocytes were selected for zona-lysis by treating with pronase $(2 \mathrm{mg} / \mathrm{ml})$ for $15 \mathrm{~min}$.
Oocytes with undigested or partially digested zona pellucida were discarded. The oocytes were successfully zona-lysed and incubated in T20 for 30 minute for expression of prominent protrusion cone. Enucleation was done manually bisecting with microblade in cytochalasin-B droplets. Goat fetus of around 60 days of age was collected from local slaughterhouse and was used for development of fibroblast cells monolayer to be used as nucleus donor.

Migration of cells was observed from native tissue explants after $24 \mathrm{hrs}, 48 \mathrm{hrs}$ and $72 \mathrm{hrs}$. Subculture (passage) was done when confluence $60-70 \%$ was achieved in new culture flask after trypsinization and at least thrice passages were done prior to use as donor cells. After each trypsinization, overall viability of fibroblast cells were evaluated by trypan blue staining to assess live and dead counts. The enucleated oocytes (demi-oocyte) were immersed in phytohaemagglutinin followed by incubation in T2 (TCM-199 with $2 \%$ FBS) to fuse with polyethylene glycol (PEG) treated fibroblast cells to produce couplets and triplets leading to formation of reconstructed oocytes. The produced reconstructed oocytes were treated with $\mathrm{Ca}$ ionophore and 6-DMAP (Dimethylaminopurine) for parthenogenetic activation. For in-vitro culture of embryos, modified synthetic oviductal fluid (mSOF) culture medium was used.

\section{Results and Discussion}

\section{Recovery of oocytes}

The result of oocyte recovery is presented in Table 1 and figure 1. A total of 200 goat ovaries were collected from local slaughterhouses and 670 numbers of oocytes were recovered by aspiration technique. The recovery of A and B grade oocytes per ovary was higher than that of $\mathrm{C}$ grade oocytes. The 
average number of oocytes recovered per ovary was found to be 3.36. Agrawal et al., (1995) reported that slaughterhouse ovaries are the cheapest and abundant source of collection of oocytes and production of embryos in-vitro. Regarding collection technique, Wang et al., (2007) recovered oocytes from ovaries using four techniques viz. slicing, puncture, aspiration I and aspiration II. Many workers reported that puncture and slicing can yield more numbers of cumulus-oocyte-complexes (COCs) as compared to aspiration technique; however, aspiration can yield more numbers of good quality oocytes (Wani et al., 2000).

A varied result of oocyte recovery by aspiration technique was reported by various workers which may be due to breed differences (Wang et al., 2007), reproductive stage (Mondal et al., 2008), nutritional status of the animal, season, etc. Our results are nearly similar to the findings of Hoque et al., (2011) who found 3.28 COCs per ovary and Wang et al., (2007) reported 2.9 to 3.1 oocytes per ovary. Higher and lower oocyte recoveries have been reported by Wani et al., (2000) by aspirating sheep oocyte. These variations might be predominantly due to species differences.

\section{In vitro maturation (IVM) of oocytes}

The results of IVM are presented in Table 2. The maturation evaluation was done by observing cumulus cell expansion (Figure 2) and aceto-orcein staining (Figure 3) for the presence of polar body. The average maturation performance of oocytes on the basis of cumulus cell expansion was found to be 60.37 per cent. The maturation rate was higher in A grade oocytes followed by grade B. Oocytes with intact cumulus or at least four layers of cumulus cells gave good results for IVM and IVF (Wang et al., 2007). Moreover, denuded oocytes or with few cumulus cells have less capacity for IVM and IVF as reported by Mondal et al., (2008). The cumulus cells are known to supply nutrients energy substrates, messenger molecules for the development of oocytes and to mediate the effects of hormones on the COCs (Sutton et al., 2003). Low maturation was reported from bovine oocytes when cumulus cells are removed before maturation in-vitro (Wani et al., 2000). The presence of cumulus cells increases fertilization and embryo developmental competency compared to that of denuded or corona-enclosed oocytes (Stojkovic et al., 2001).

Similar developmental pattern was also reported in goat by Rahman et al., (2006), where significantly higher maturation rate was observed in oocytes surrounded by more than five layers of COCs than those with less than five layers of COCs and denuded oocytes. Serum along with hormone supplementation can yield higher maturation performance (Wani et al., 2000). Garg and Purohit (2007) reported maturation rate of $65.62 \%$ in media supplemented with FSH, LH and estradiol. Similar result was also reported by Vajta et al., (2003) who recorded $63.65 \%$ maturation in TCM-199 supplemented with fetal calf serum $(10 \%)$, FSH $(0.5 \mu \mathrm{g} / \mathrm{ml}), \mathrm{LH}(5 \mu \mathrm{g} / \mathrm{ml})$ and estradiol $(1 \mu \mathrm{g} / \mathrm{ml})$.

\section{Enucleation, cell fusion, activation of oocyts and embryo culture}

The results of oocytes enucleation, reconstruction of oocytes and embryo production rates are given in table 3 . The respective figures of different post maturational processed oocytes, fibroblast cell culture (primary), first sub culture (passage) of fibroblast cells, second sub culture (passage) of fibroblast cells, trypsinized fibroblast cells after trypan blue staining, triplet, reconstructed oocyte and cloned embryos were shown in the figure $4,5,6,7,8,9,10$ and 11. 
Table.1 Recovery of different graded oocytes

\begin{tabular}{|l|l|l|l|l|l|}
$\begin{array}{l}\text { Total } \\
\text { number of } \\
\text { ovary }\end{array}$ & $\begin{array}{l}\text { Total } \\
\text { number } \\
\text { oocytes }\end{array}$ & $\begin{array}{l}\text { Grades } \\
\text { oocyte }\end{array}$ & $\begin{array}{l}\text { No of oocyte } \\
\text { recovered }\end{array}$ & $\begin{array}{l}\text { Rate (\%) of } \\
\text { oocyte } \\
\text { recovery }\end{array}$ & $\begin{array}{l}\text { Oocyte } \\
\text { recovery per } \\
\text { ovary }\end{array}$ \\
\hline $\mathbf{2 0 0}$ & 670 & A & 265 & 39.55 & $\mathbf{1 . 3 3}$ \\
\hline & B & 257 & 38.35 & $\mathbf{1 . 2 9}$ \\
\hline & C & 148 & 22.09 & $\mathbf{0 . 7 4}$ \\
\hline & Overall & $\mathbf{6 7 0}$ & & $\mathbf{3 . 3 6}$ \\
\hline
\end{tabular}

Table.2 In vitro maturation of oocytes

\begin{tabular}{|l|l|l|}
\hline Oocytes Grade & Maturation & \\
\hline A $(\mathbf{2 6 5})$ & No. & Rate $(\%)$ \\
\hline B (257) & 210 & 79.24 \\
\hline C (148) & 175 & 68.09 \\
\hline Overall $(\mathbf{6 7 0})$ & 50 & 33.78 \\
\hline
\end{tabular}

Table.3 Oocytes enucleation, reconstruction of oocytes and embryo production

\begin{tabular}{|c|c|c|c|c|c|c|c|}
\hline \multirow{2}{*}{$\begin{array}{l}\text { Matured } \\
\text { oocytes }\end{array}$} & \multicolumn{2}{|c|}{ Enucleation } & \multicolumn{3}{|c|}{ Reconstructed oocyte } & \multicolumn{2}{|c|}{ Embryo Production } \\
\hline & No. & Rate $(\%)$ & $\begin{array}{l}\text { Pairing } \\
\text { No. }\end{array}$ & $\begin{array}{l}\text { Success } \\
\text { No. }\end{array}$ & $\begin{array}{l}\text { Success } \\
\text { Rate } \\
(\%)\end{array}$ & No. & $\%$ \\
\hline$A(210$ & 180 & 85.71 & 90 & 25 & 27.78 & 2 & 8.00 \\
\hline B (175) & 166 & 94.85 & 83 & 20 & 24.09 & 1 & 5.00 \\
\hline $\mathrm{C}(50)$ & 23 & 46.00 & 10 & 2 & 20.00 & & \\
\hline Overall & 369 & 75.52 & 183 & 47 & 23.95 & 3 & $6.38 \%$ \\
\hline
\end{tabular}
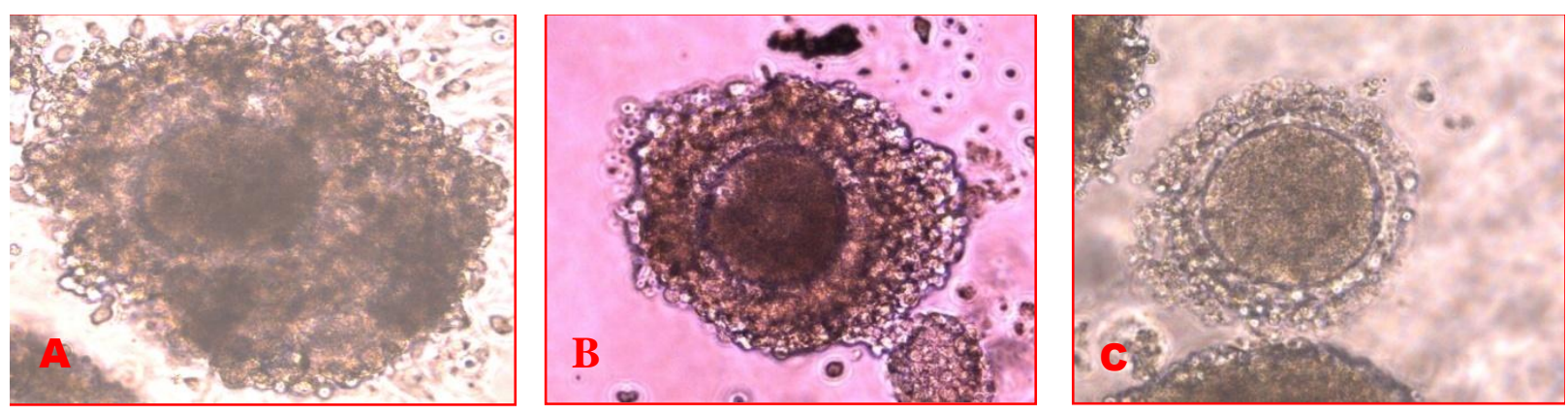

FIGURE 1: OOCYTES BEFORE MATURATION (A) Grade A, (B) Grade B, (C) Grade C. [20 × 10] 

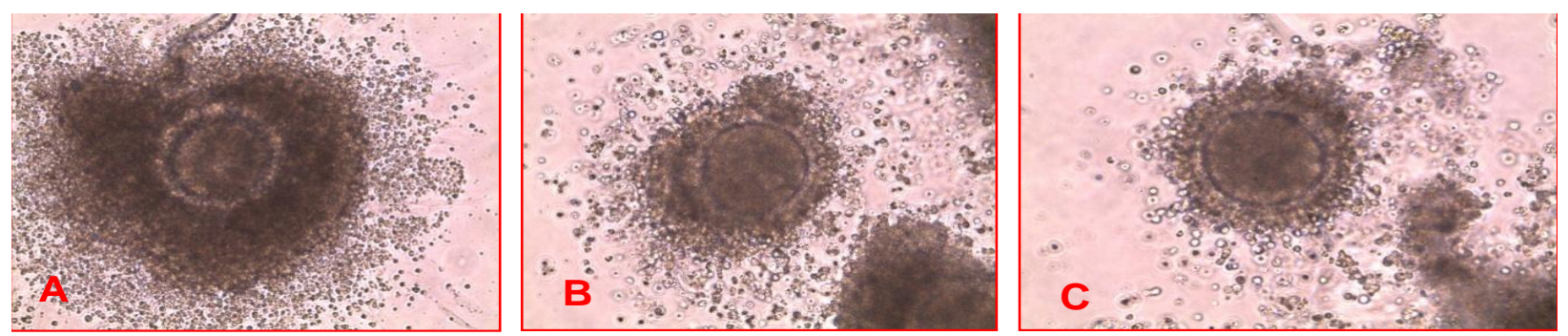

FIGURE 2: IN VITRO MATURED OOCYTES WITH CUMULUS CELL EXPANSION

(A) Grade A, (B) Grade B, (C) Grade C. [10 × 10]
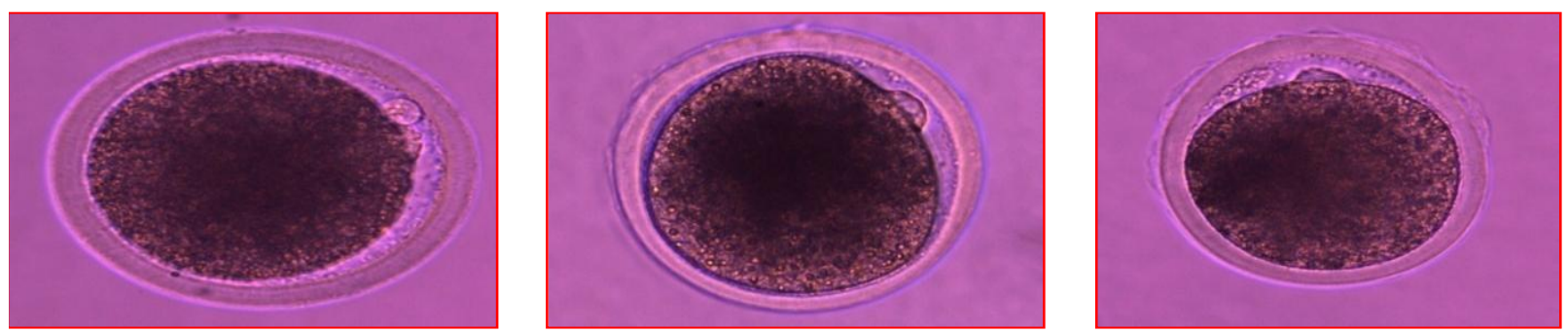

FIGURE 3: EXTRUSION OF POLAR BODY IN ACETO-ORCEIN STAINED IVM OOCYTE. $[10 \times 20]$
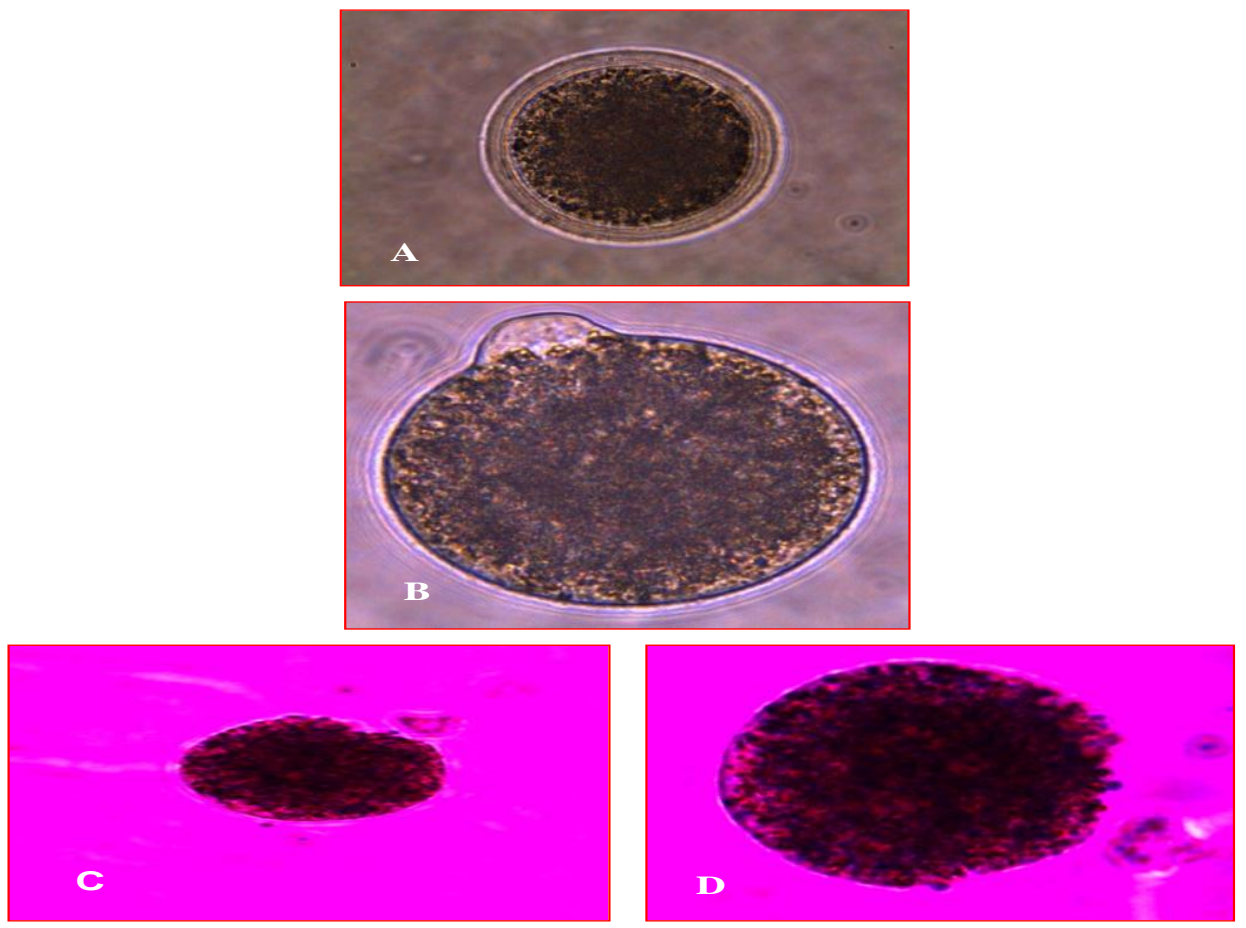

FIGURE 4: DIFFERENT POST MATURATIONAL PROCESSED OOCYTES

(A) Denuded oocyte $[20 \times 10]$

(B) Oocytes after zona lysis [20 $\times 10]$

(C \&D) Enucleated demi oocyte $[10 \times 10]$ 

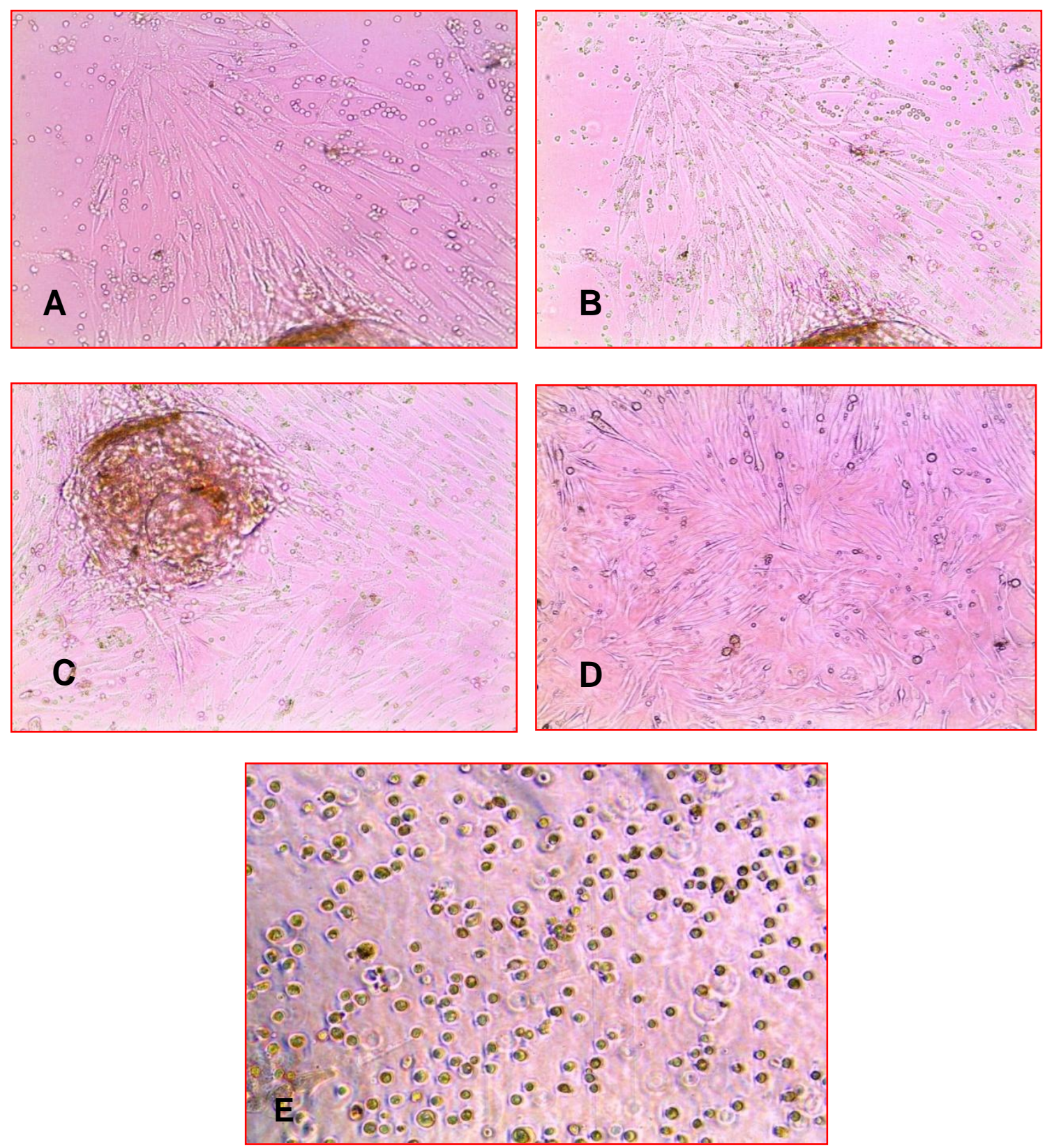

FIGURE 5: FIBROBLAST CELL CULTURE (PRIMARY)

(A) Fibroblast cell migration after 24 hrs [20 $\times 10]$

(B) $48 \mathrm{hrs}[20 \times 10]$

(C) 72 hrs [20 $\times 10]$

(D) 6 days $[10 \times 10]$

(E) Trypsinized [20 × 10] 

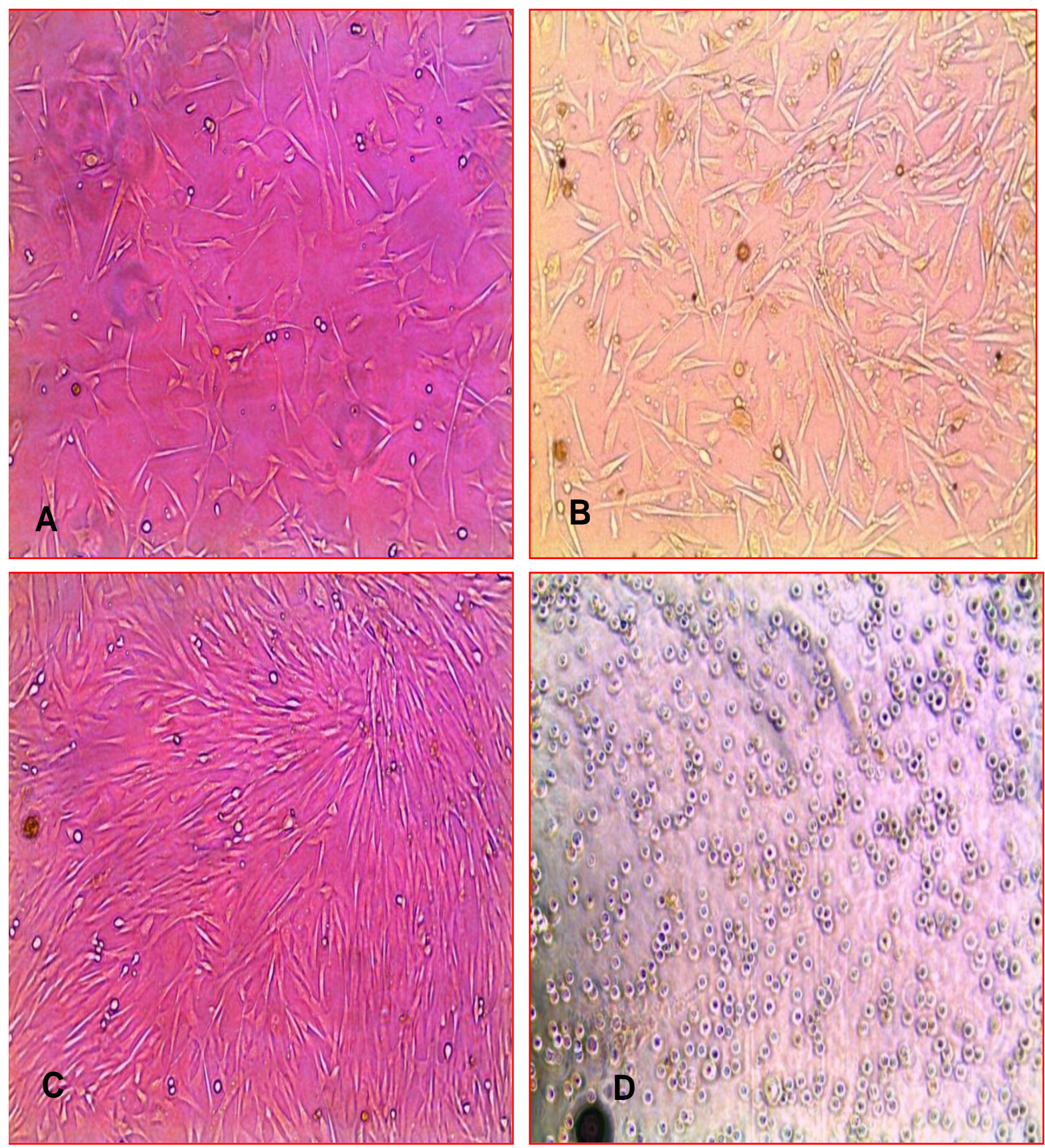

FIGURE 6: FIRST SUB CULTURE (PASSAGE) OF FIBROBLAST CELLS.

(A) After 48 hrs [10 $\times 10]$,

(B) 72 hrs [10 $\times 10]$,

(C) 6 days [ $4 \times 10]$,

(D) Trypsinized [10 $\times 10]$ 

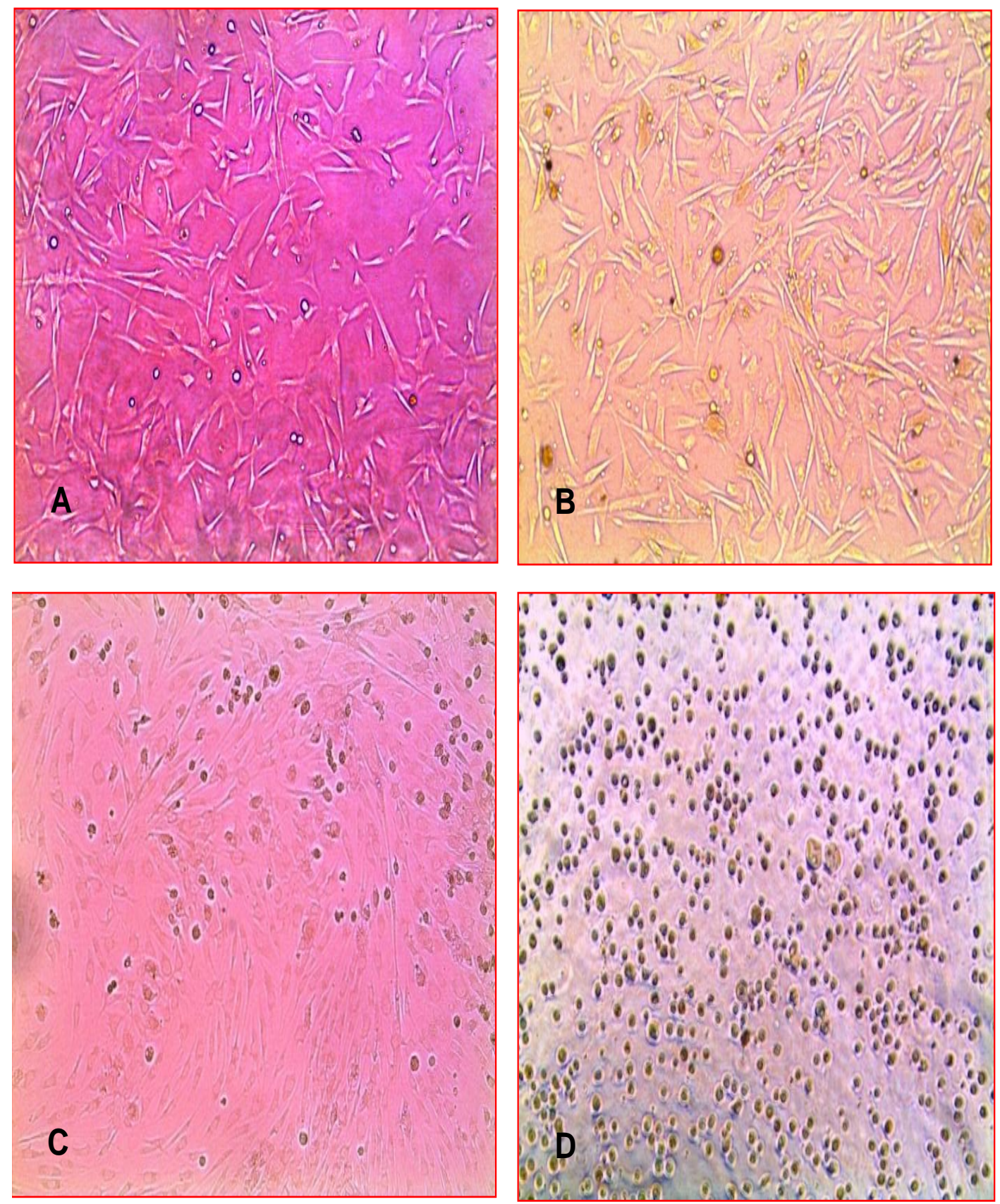

FIGURE 7: SECOND SUB CULTURE (PASSAGE) OF FIBROBLAST CELLS.
(A) $48 \mathrm{hrs}[10 \times 10]$
(B) $72 \mathrm{hrs}[10 \times 10]$
(C) 6 days $[10 \times 10]$
(D) Trypsinized [10 $\times 10]$ 

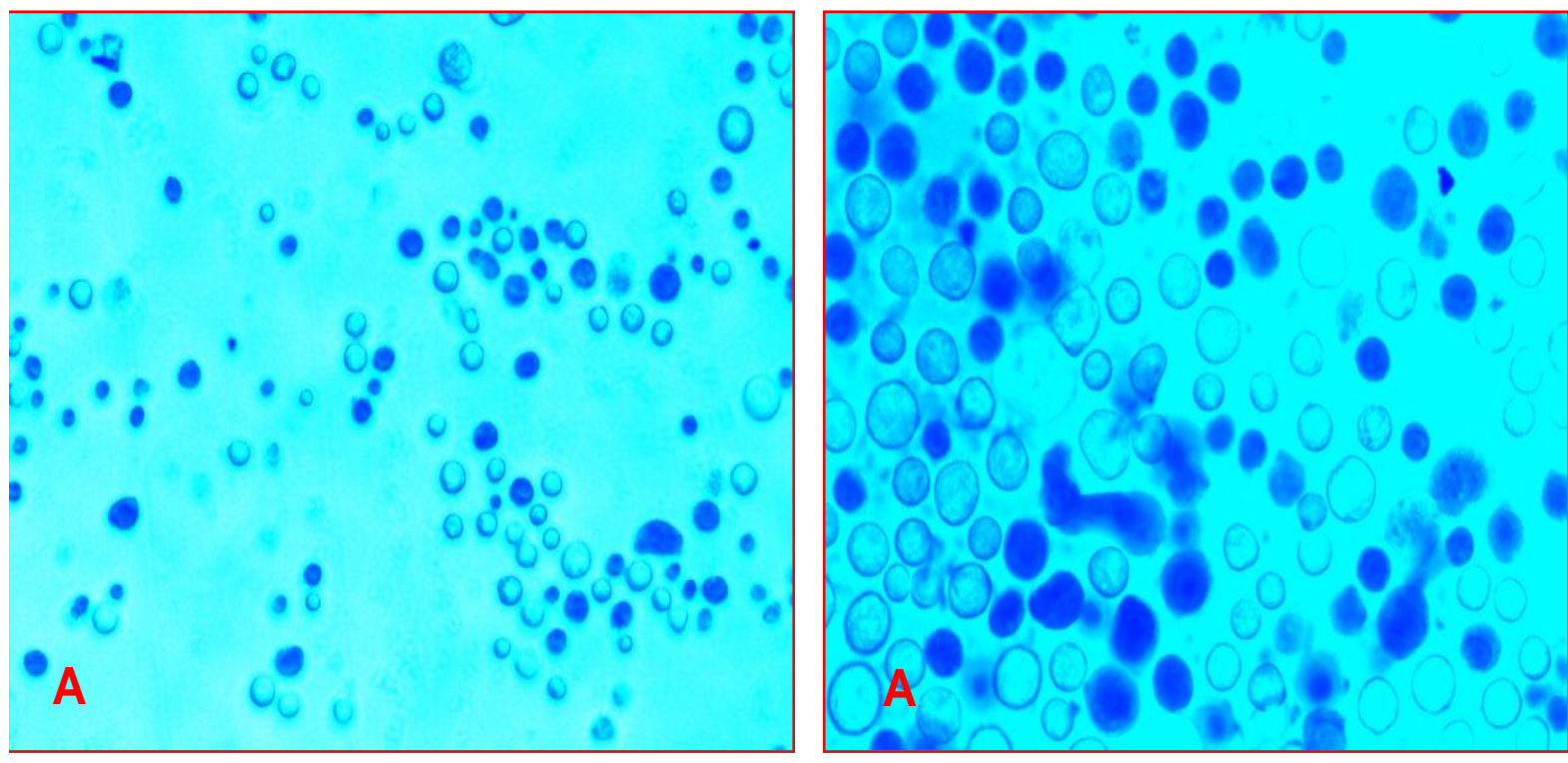

FIGURE 8: TRYPSINIZED FIBROBLAST CELLS AFTER TRYPAN BLUE STAINING

$A[10 \times 10], \quad B[40 \times 10]$

(Stained or partially stained one dead cells)

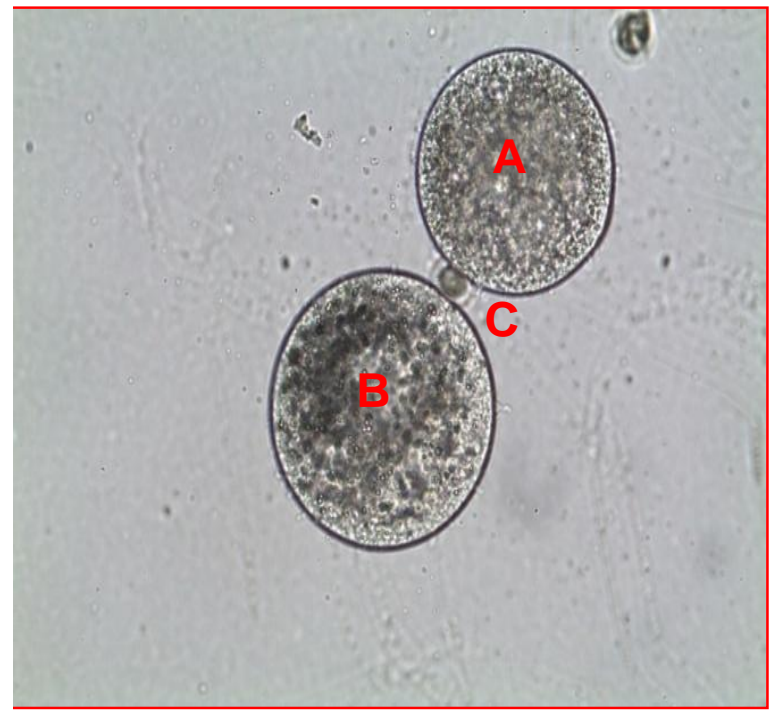

FIGURE 9: TRIPLET

$(\mathrm{A} \& \mathrm{~B})$ Demi oocyte,

(C) Fibroblast cell $[10 \times 20]$

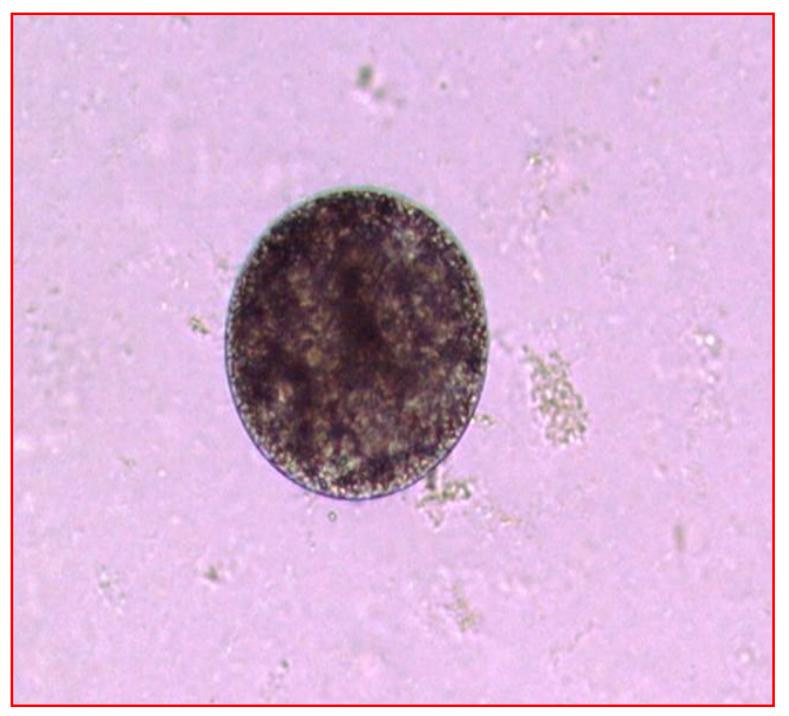

FIG 4.10: RECONSTRUCTED OOCYTE $[20 \times 10]$ 

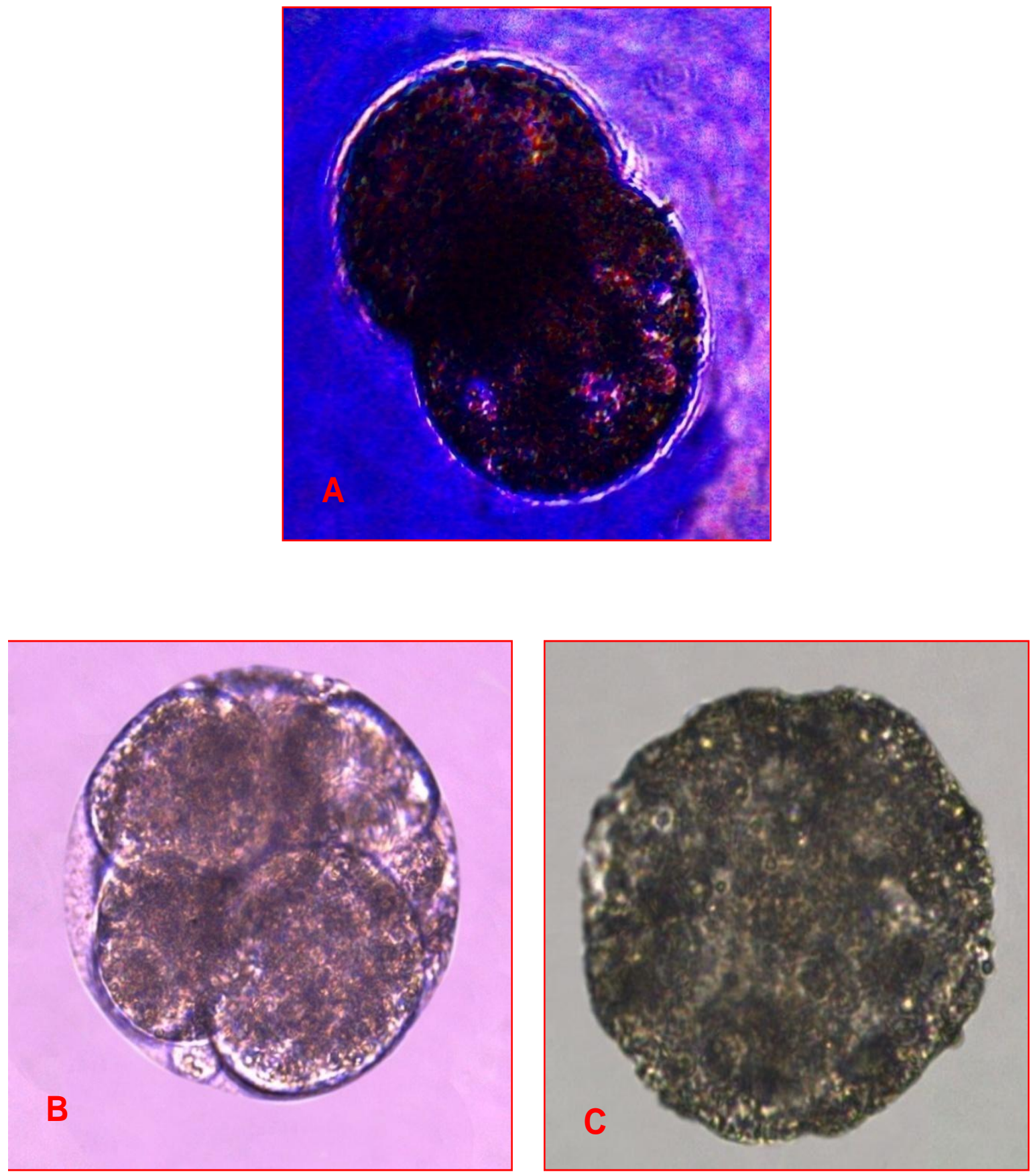

FIGURE 11: CLONED EMBRYOS

(A) 2-CELL $[40 \times 10]$

(B) 5-6 CELL [40 ×10]

(C) Compact Morula $[20 \times 10]$ 
In the present study, a total of 369 numbers of protrusion cone bearing oocytes were processed for enucleation. Enucleated performance was found to be 75.52 per cent. A total of 47 reconstructed oocytes were produced with 23.95 per cent success rate during the whole experiment period. The overall percentage of embryo production was 6.38 per cent. The oocytes were denuded by treating in hyaluronidase $(0.5 \mathrm{mg} / \mathrm{ml})$ solution followed by zona-lysis in pronase $(2 \mathrm{mg} / \mathrm{ml})$. Hyaluronidase is being extensively used for removal of cumulus cells to denude the mature oocytes for in-vitro embryo production. Zona-lysis using pronase is an efficient and harmless method. Phytohaemagglutinin was found to be efficient and reliable for pairing of cytoplasts and somatic cell (Vajta, 2007). In the present study, enucleation was found to be efficient and extruded polar body exhibited a prominent protrusion cone on their surface, which might describe the cumulative effect of pronase and subsequent incubation in T2 (Vajta et al., 2005). Chemicals like polyethylene glycol (PEG) is used for fusion of leucocytes (Rank et al., 2004), kidney fibroblast cells, mouse LM cell line, etc. for production of hybrid cells colonies. However, PEG is highly toxic (Gefter et al., 1977). The evidence of toxicity is observed following exposure to 50\% PEG beyond $2 \mathrm{~min}$. Wani et al., 2000 reported that increased period of exposure to PEG increases the net fusion index but decreases self-viability. During the experiment, the electro cell manipulator could not be procured, hence, cell fusion was tried using PEG. The lower rate of embryo production might be due to use of PEG which is known to have cytotoxic effects (Gefter et al., 1977). Selokar et al., (2012) used the electrical pulse for cell fusion which has less negative impact on cells. Furthermore, they cultured the parthenogenesis activated oocytes in a defined media, viz. Research Vitro Cleave (RVCL Cook ${ }^{\circledR}$, Australia) which is specially meant for cloned embryo culture. Another emerging clone embryo culture media is modified synthetic oviductal fluid (mSOF) but less superior than RVCL. Jena et al., (2012) reported $9.6 \%$ blastocyst in $\mathrm{mSOF}$ compared to $14.1 \%$ in RVCL.
From the present study it was found that Slaughterhouse waste of gravid uterus could be utilized for development of fetal fibroblast cells to be used as nuclear donor in HMC. Grade A oocytes yielded higher maturation rate $(79.24 \%)$ and pairing to produce reconstructed oocytes and subsequent development to cloned embryos. PEG (50\%) could be used for fusion of somatic cell with oocytes $(23.95 \%)$ to produce reconstructed oocytes, however, subsequent development was found to be poor. The mSOF- based medium (modified synthetic oviductal fluid) was found to be promising for goat embryo production, supplemented with BSA, essential amino acid and non-essential amino acid.

\section{Acknowledgment}

The Authors wish to express their sincere gratitude to the State Biotech Hub (SBT), Department of Animal Biotechnology, Department of Veterinary Physiology, College of Veterinary Science, A.A.U., khanapara, Guwahati for providing the opportunity to carry out the research work. The Authors also wish to express their gratitude to the Dean, the Director of Post Graduate Studies officials and other staff member of the college faculty, who rendered their help during the whole period of the research work.

\section{References}

Agrawal, K.P., T, Sharma, C. Sexana, and Sharma, N. 1995. Chronology of first meiotic events of caprine oocytes matured in vitro. Indian Journal of Animal Science. 65: 285-288.

Garg, N., and Purohit, G.N. 2007. Effect of different cryoprotectant concentrations for ultrarapid freezing of immature goat follicular oocytes on their subsequent maturation and fertilization in vitro. Animal Reproduction. 4: 113-118.

Gefter, M.L., D.H. Marulies and Schraf, M.D. 1977. A simple method for polyethylene glycol-promoted hybridization of mouse 
myeloma cells. Somatic Cell Genetic. 3 (2): 231-236

Hoque, S.A.M., S.K. Kabira, M. Khandoker, A. Mondal and Tareq K. 2011. Effect of collection techniques on cumulus oocyte complexes (COCs) recovery, in vitro maturation and fertilization of goat oocytes. African Journal of Biotechnology. 10(45): 9177-9181.

Jena, M.K., D. Malakar, A.K. De, S. Garg, Y.S. Akshey, R, Dutta, S. Sahu, A.K. Mohanty and Kaushik, J.K. 2012. Handmade cloned and parthenogenetic goat embryos - A comparison of different culture media and donor cells. Small Ruminant Research. 10: 255-262.

Mondal, A., M. Khandoker, M.A. Mondal and Pervage, S. 2008. In vitro production of goat embryos in Bangladesh. Bangladesh Journal of Animal Science. 37: 1-9.

Rahman, A., R.B. Abdullah and Khadijiah, W.E. 2006. Goat embryo development following in vitro maturation and intracytoplasmic sperm injection according to oocyte grading. Proceedings of $11^{\text {th }}$ Biological Sciences Graduate Conference, December 15-17, Bangkok, Thailand. 143-143.

Rank, D.N., C.G. Joshil, V. Thiagarajan, P. Kanakaraj and Krishnan, A.R. 2004. Development of somatic cell hybrids using buffalo leucocytes and mouse cell line. Indian Veterinary journal. 81: 156159.

Selokar, N.L., R.A. Shah, A.P. Saha, M. Muzaffar, M. Saini, M.S. Chauhan, R.S. Manik, P. Palta and Singla, S.K. 2012. Effect of post-fusion holding time, orientation and position of somatic cell- cytoplasts during electrofusion on the development of handmade cloned embryos in buffalo (Bubalus bubalis). Theriogenology. 78: 930-936.

Stojkovic, M., S.A. Machado, P. Stojkovic, V. Zakhartchenko and Hutzler, P. 2001. Mitochondrial distribution and adenosine triphosphate content of bovine oocytes and after in vitro maturation: Correlation with morphological criteria and developmental capacity after in vitro fertilization and culture. Biol Reprod. 64: 904-909.

Sutton, M.L., R.B. Gilchrist and Thompson JG. 2003. Effects of in vivo and in vitro environments on the metabolism of cumulus-oocyte complex and its influence on the oocyte developmental competence. 9: 35-48.

Vajta, G. 2007. Handmade cloning: the future way of nuclear transfer? Trends Biotechnol. 25: 250-253.

Vajta, G., P.M. Kragh and Mtango NR. 2005. Handmade cloning approach: potentials and limitations. Reprod Fertil Dev. 17: 97-112.

Wang, Z.G., Z.R. Xu and Yu SD. 2007. Effects of oocyte collection techniques and maturation media on in vitro maturation and subsequent embryo development in Boer goat. Czech J Anim Sci, 52 (1): 2125.

Wani, N.A., G.M. Wani, M.Z. Khan and Salahudin, S. 2000. Effect of oocyte harvesting techniques on in vitro maturation and in vitro fertilization in sheep. Small Ruminant Research. 36: 6367.

\section{How to cite this article:}

Monika Borah, Nikhil C. Nath, Probodh Borah, Biju Borah, Girin Hazarika and Padma L. Borah. 2018. Handmade Cloning for Embryo Production in Goat, Assam, India. Int.J.Curr.Microbiol.App.Sci. 7(05): 2518-2529. doi: https://doi.org/10.20546/ijcmas.2018.705.290 